\title{
Komposisi Dan Strukutur Tegakan Pada Areal Tebangan Tebang \\ Pilih Tanam Indonesia Intensif (TPTII) Di IUPHHK PT. Sari Bumi Kusuma Kalimantan Tengah
}

\author{
Kamaludin \\ Fakultas Pertanian Universitas Kapuas Sintang \\ e-mail : kamaludinkamal27@yahoo.co.id
}

\begin{abstract}
Abstrak : Penelitian ini dilakukan dengan pembuatan Petak Ukur seluas $1 \mathrm{Ha}$ (ukuran 100 x $100 \mathrm{~m}$ ). Pengambilan data dalam PU menggunkan metode petak kuadrat, dimana ukuran $20 \mathrm{~m}$ x $20 \mathrm{~m}$ untuk tingkat pohon, $10 \mathrm{~m}$ x $10 \mathrm{~m}$ untuk tingkat tiang, $5 \mathrm{~m} \times 5 \mathrm{~m}$ untuk tingkat pancang dan $2 \mathrm{~m} \times 2 \mathrm{~m}$ untuk tingkat semai. PU dibuat pada area hutan murni dan area bekas tebangan yakni 5 tahun setelah tebangan. Parameter yang diamati adalah jenis tumbuhan, DBH $(\mathrm{cm})$, jumlah individu. Analisis potensi dengan menggunakan nilai INP (Indeks Nilai Penting).

Hasil penelitian menunjukan Komposisi Jenis Vegetasi yang terdapat pada Areal ET +5 adalah sebanyak 24 Jenis tingkat semai, 29 Jenis tingkat pancang, 15 jenis tingkat tiang dan 32 jenis tingkat Pohon, sedangkan pada areal sebelum penebangan terdapat 22 jenis tingkat semai, 38 jenis tingkat pancang, 35 jenis tingkat tiang dan 61 jenis tingkat pohon dan Struktur tegakan diliat dari kerapatan pada areal ET +5 yaitu tingkat Semai didominasi oleh Medang dan Ubah, tingkat Pancang Medang dan kumpang, tingkat Tiang Ubah dan Medang, dan tingkat Pohon Ubah dan Meranti Merah, sedangkan pada areal sebelum penebangan tingkat semai di dominasi oleh Meranti Kuning dan Ubah, tingkat pancang didominasi oleh Mahabai dan Ubah, tingkat tiang Ubah dan Sampak dan tingkat pohon didominasi oleh Ubah dan Medang
\end{abstract}

Kata Kunci : Komposisi, Strukutur, TPTII, bekas Areal Tebangan ET + 5

\section{PENDAHULUAN}

Dalam rangka pengusahaan hutan produksi guna menjamin kelestarian produksi dan fungsi ekologis hutan alam produksi di Indonesia, telah dikeluarkan Surat Keputusan Menteri Kehutanan No. 485/Kpts-II/1989 tentang Sistem Silvikultur Pengelolaan Hutan Alam Produksi di Indonesia. Dalam Surat Keputusan tersebut antara lain ditetapkan bahwa pengelolaan hutan alam produksi dapat dilakukan dengan Sistem Silvikultur Tebang Habis dengan Permudaan Alam (THPA), Tebang Habis dengan Permudaan Buatan (THPB) dan Tebang Pilih Tanam Indonesia (TPTI).

Dari pelaksanaan kegiatan pengusahaan hutan yang telah berjalan, jika diadakan penilaian umum maka secara garis besar dapat ditemukan dua hal yang tidak mungkin dipungkiri. 
Pada satu sisi, keterlaksanaan pengusahaan hutan telah menyebabkan meningkatnya peranan sektor kehutanan di dalam perekonomian negara. Tetapi disisi lain, keterlaksanaan tersebut telah menyebabkan timbulnya kerusakan pada sumberdaya hutan itu sendiri, akan tetapi masih perlu diingat, kendatipun panduan sistem-sistem silvikultur diatas diberlakukan dan diikuti akan tetapi masih terdapat kelemahan-kelemahan terutama pada saat pelaksanaannya. Oleh karena itu, guna tercapainya kelestarian ekologi dan kelestarian hasil hutan yang produktif dan optimal maka Departemen

Kehutanan mengembangkan suatu sistem silvikultur yang merupakan usaha penyempurnaan dari sistem-sistem sebelumnya yaitu Sistem Silvikultur Tebang Pilih Tanam Indonesia Intensif
(TPTII) atau lebih dikenal dengan Sistem Silvikultur Intensif. Penelitian ini dilaksanakan sebagai pemberi informasi awal pelaksanaan TPTII sehingga dapat diketahui dampak yang ditimbulkan serta tingkat keberhasilan dari pelaksanaan sistem ini.

\section{METODOLOGI PENELITIAN}

Metode yang akan digunakan dalam penelitian adalah petak yaitu dengan membuat plot pengamatan permanen, yaitu pada lokasi pemanenan kayu. Pada lokasi dibuat plot pengamatan contoh dibuat petak contoh dan sub-sub petak contoh dengan ukuran sebagai berikut : tingkat pohon ukuran petak $20 \times 20 \mathrm{~m}$, tingkat tiang $10 \times 10 \mathrm{~m}$, tingkat pancang $5 \times 5 \mathrm{~m}$, dan tingkat semai $2 \times 2 \mathrm{~m}$.

$100 \mathrm{~m}$

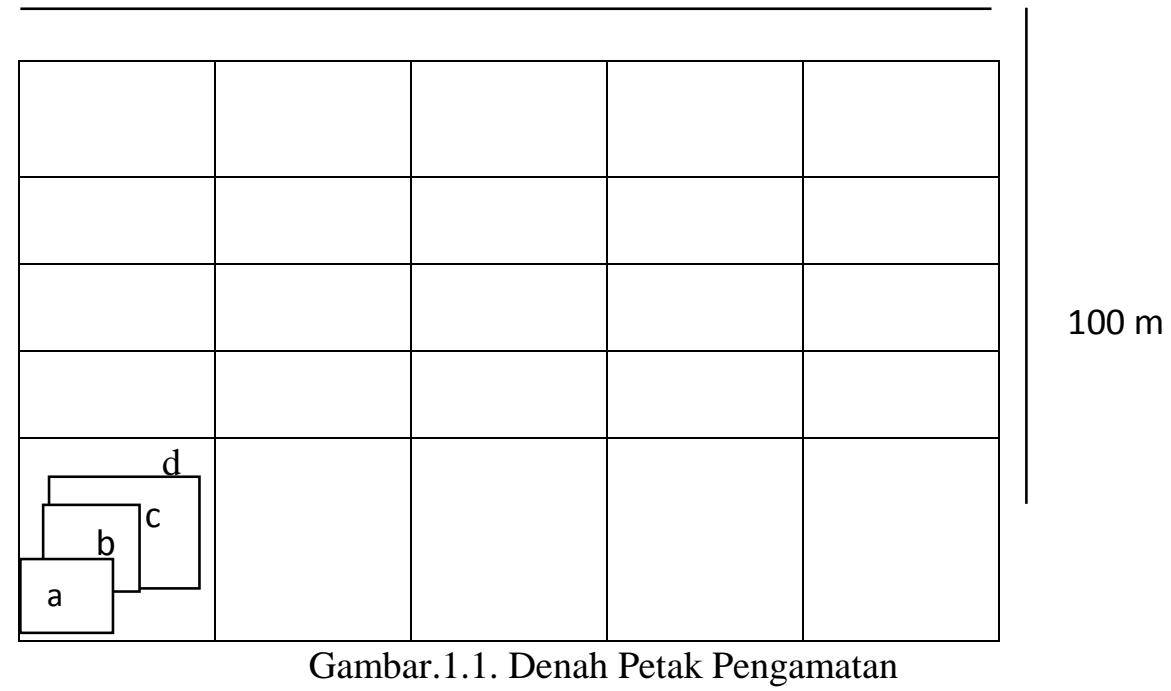


Keterangan:
$\mathrm{A}=$ Sub petak pengamatan untuk tingkat semai $(2 \times 2 \mathrm{~m})$
$\mathrm{b}=$ Sub petak pengamatan untuk tingkat pancang $(5 \times 5 \mathrm{~m})$
$\mathrm{c}=$ Sub petak pengamatan untuk tingkat tiang $(10 \times 10 \mathrm{~m})$
$\mathrm{d}=$ Sub petak pengamatan untuk tingkat pohon $(20 \times 20 \mathrm{~m})$

WAKTU DAN TEMPAT 2 (dua) minggu efektif berada di

\section{PENELITIAN}

Penelitian ini dilaksanakan di Kawasan Hutan Produksi PT. Sari Bumi Kusuma Kalteng Kecamatan Menukung Kabupaten Melawi, selama lebih kurang lapangan. Pelaksanaan kegiatan penelitan dilakukan pada akhir bulan April 2017 sampai dengan awal bulan Mei 2017

\section{HASIL DAN PEMBAHASAN}

\section{Hasil Penelitian}

\section{Komposisi Tegakan Tinggal Pada Areal Sebelum Tebang dan ET+5}

Tabel 1. Jumlah Jenis Tegakan yang ditemukan pada areal hhutan Sebelum Tebang dan ET+5.

\begin{tabular}{|c|c|c|c|c|c|}
\hline \multirow{2}{*}{ No } & \multirow{2}{*}{ Lokasi Penelitian } & \multicolumn{4}{|c|}{ Tingkat Pertumbuhan } \\
\hline & & Semai & Pancang & Tiang & Pohon \\
\hline 1. & Sebelum Tebang & 22 & 38 & 35 & 61 \\
\hline 2. & $\mathrm{ET}+5$ & 24 & 29 & 15 & 32 \\
\hline
\end{tabular}

Sumber : Hasil Analisis Data, 2017.

Tabel 2. Komposisi Hutan Sebelum Tebang dan ET+5 dilihat dari Kerapatan (N/Ha) dan Frekuensi

\begin{tabular}{|c|l|c|c|c|c|c|c|c|c|}
\hline \multirow{2}{*}{ No } & \multirow{2}{*}{ Kondisi Hutan } & \multicolumn{2}{|c|}{ Semai } & \multicolumn{2}{c|}{ Pancang } & \multicolumn{2}{c|}{ Tiang } & \multicolumn{2}{c|}{ Pohon } \\
\cline { 3 - 10 } & & $\mathrm{K}$ & $\mathrm{F}$ & $\mathrm{K}$ & $\mathrm{F}$ & $\mathrm{K}$ & $\mathrm{F}$ & $\mathrm{K}$ & $\mathrm{F}$ \\
\hline 1 & Sebelum Tebang & 10.100 & 1.88 & 2.688 & 5.2 & 252 & 2.4 & 209 & 5.76 \\
2 & Et+5 & 9.000 & 2.72 & 1.488 & 2.92 & 284 & 2.08 & 149 & 4.56 \\
\hline
\end{tabular}

Sumber : Hasil Analisis Data, 2017 
Tabel 3. Daftar Jenis Dominan Terbesar Hutan Sebelum Tebang dan ET +5

\begin{tabular}{|c|c|c|c|c|c|c|c|c|c|}
\hline No & $\begin{array}{c}\text { Kondisi } \\
\text { Hutan }\end{array}$ & Semai & INP & Pancang & INP & Tiang & INP & Pohon & INP \\
\hline & Sebelum & Medang & 31.8726 & Mahabai & 25.8242 & Ubah & 48.1039 & Ubah & 67.8939 \\
\hline 1. & Tebang & Ubah & 27.7649 & Ubah & 22.500 & Garung & 24.6088 & M.Kuning & 32.0825 \\
\hline & & M.Kuning & 26.0375 & Medang & 12.1062 & Sampak & 23.8929 & Medang & 18.7342 \\
\hline \multirow[t]{3}{*}{2.} & $\mathrm{ET}+5$ & Medang & 39.1176 & Kumpang & 27.6771 & Ubah & 88.7263 & Ubah & 53.9447 \\
\hline & & Ubah & 32.8431 & Medang & 26.3073 & Medang & 48.2265 & M.Merah & 40.1009 \\
\hline & & Mahabai & 14.0196 & Timau & 14.37 .62 & M.Merah & 11.5321 & Medang & 21.7542 \\
\hline
\end{tabular}

Sumber : Hasil Analisis Data, 2017

Tabel 4. Indek Kesamaan dan Ketidaksmaan Jenis yang ditemukan pada Sebelum Tebang dan ET+5.

\begin{tabular}{|c|l|c|c|}
\hline No & \multicolumn{1}{|c|}{ Tingkat Pertumbuhan } & IS & ID \\
\hline 1. & Semai & 0.27 & 0.73 \\
2. & Pancang & 0.26 & 0.74 \\
3. & Tiang & 0.32 & 0.68 \\
4. & Pohon & 0.31 & 0.69 \\
\hline
\end{tabular}

Sumber : Hasil Analisis Data, 2017

\section{Struktur Tegakan Tinggal Pada Areal Sebelum Tebang dan ET+5}

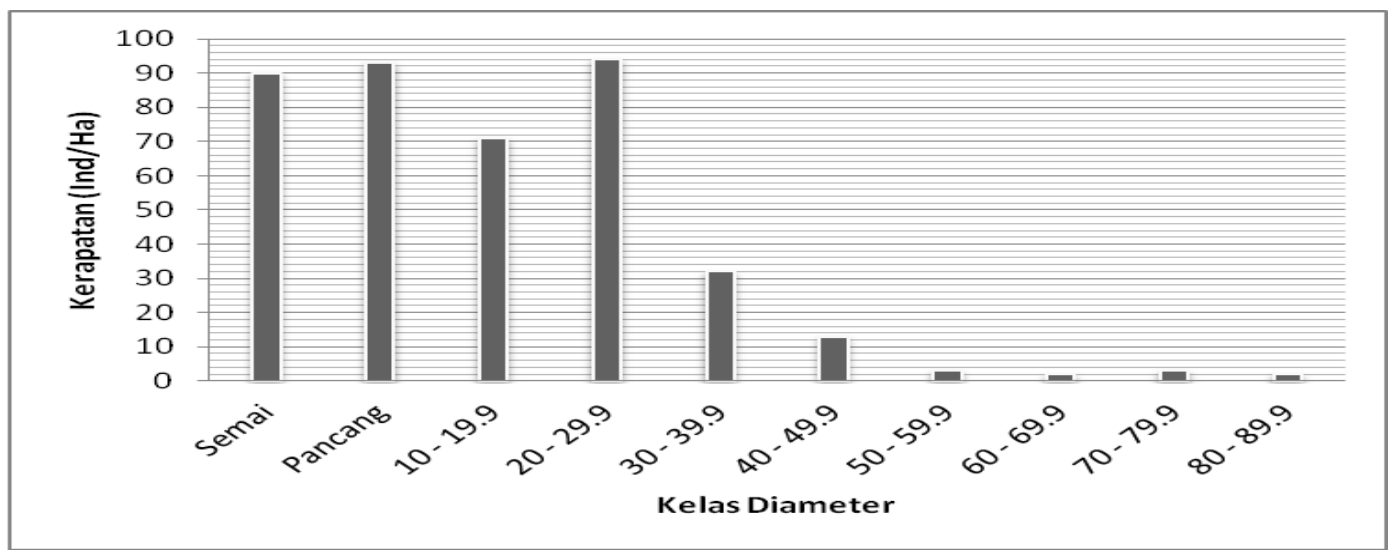

Gambar 1.Kerapatan dan Kelas Diameter Jenis ET+5 


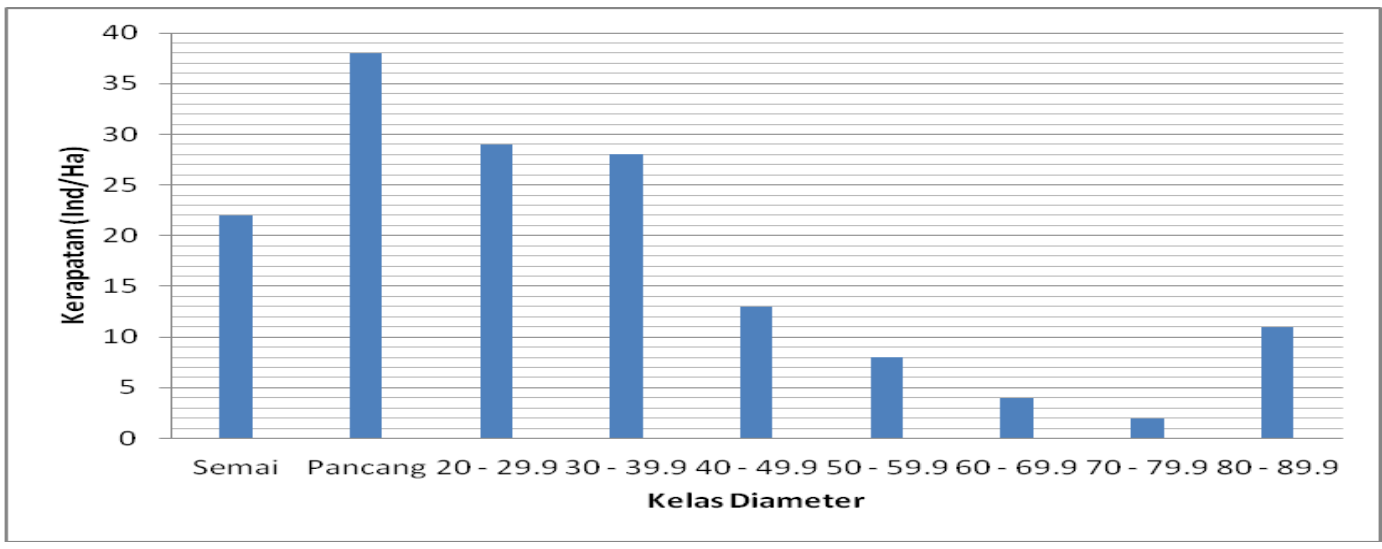

Gambar 2. Kerapatan dan Kelas Diameter Jenis Sebelum Penebangan.

\section{PEMBAHASAN}

Keanekaragaman jenis di hutan tropika basah sangat besar dan kompleks, serta keberadaannya saling berpengaruh dan beritraksi terhadap sifat genetik dan ekositemnya, jumlah jenis semai, pancang,tiang dan pohon yang ditemukan pada Areal sebelum Penebangang dan Et+5 dapat dilihat pada Tabel 1 dapat dilihat bahwa jenis dan komposisi pada semua tingkatan vegetasi mengalami penurunan terkecuali pada jenis tingkat semai dan Komposisi pada tingkat tiang di areal ET+5 mengalami kenaikan.Komposisi jenis untuk vegetasi tingkat semai pada areal sebelum penebangan sebanyak 22 Jenis dan bertambah menjadi 24 Jenis pada ET+5, komposisi jenis untuk vegetasi tingkat Pancang pada areal sebelum penebangan sebanyak 39 Jenis dan berkurang menjadi 29 Jenis pada ET +5 , pada vegetasi tingkat Tiang ditemukan sebanyak 35 Jenis pada areal sebelum penebangan dan mengalami penurunan menjadi 15 jenis pada $\mathrm{ET}+5$, sedangakan vegetasi tingkat pohon pada areal sebelum penebangan terdapat 61 jenis dan berkurang menjadi 32 jenis pada $\mathrm{ET}+5$. Hal ini dikarenakan terjadi karena adanya kegiatan pemanenan kayu, tinggi dan rendahnya jumlah jenis pada berbagai tingkatan permudaan vegetasi yang ada menunjukan tingkat survival dari setiap tingkat tumbuhan untuk mempertahankan dan mencapai tingkat selanjutnya.

Pada Tabel 2 memperlihatkan komposisi dilihat dari Kerapatan (N/Ha) dan Frekuensinya yang terdapat pada plot pengamatan, sehingga dapat dilihat kerapatan (N/Ha) pada Areal sebelum 
penebangan mengalami penurunan

terkecuali kerapatan tingkat tiang pada ET +5 bertambah, sedangkan frekuensi pada ET +5 bertambah. Salah satu unsur untuk menetukan tipe hutan adalah melakukan perbandingan setiap dua tegakan atau komunitas petak berbeda. Cara mendapatkan nilai perbandingan terbaik dalam menggunakan koifisien kesamaan komunitas (Soerianegara dan Indrawan, 1988).

Indeks Kesamaan Komunitas (IS) merupakan suau besaran yang dapat menunjukan tingkatan kesamaan komposisi jenis dari dua komunitas yang dibandingkan. Nillai koifisien kesamaan (IS) berkisar 0-100 \%, jadi semakin dekat dengan $100 \%$ dua tegakan yang dibandingkan mempunyai kesamaan, semakin dekat dengan $0 \%$ maka dua tegakan yang dibandingkan makin berlainan (Soerianegara dan Indrawan, 1988 ). Sedangkan menurut Kusuma dan Istono (2005) IS dikatakan berbeda sama sekali apabila nilainya adalah 0 dan umumnya dua komunitas dianggap ssama apabila mempunyai IS $\geq 75 \%$.

Berdasarkan hasil pengamatan dilapangan maka dapat dilihat nilai IS antara dua lokasi yang dibandingkan berdasarkan tingkat jenis pada Tabel 4.6 , maka dua komunitas yang dibandingkan diketahui sangat berbeda, hal ini mengindikasikan bahwa gangguan yang ditimbulkan dari kegiatan pemanenan sangat besar.

Pada struktur tegakan dapat di gambarkan pada grafik yang menghubungkan antara jumlah pohon perhektar dengan kelas diameter dapat dilihat pada Gambar 1 dan Gambar 2, dari perbandingan grafik struktur tegakan jumlah pohon atau kerapatan pohon pada areal sebelum penebangan lebih tinggi daripada $\mathrm{ET}+5$,

$$
\text { Secara umum kegiatan }
$$
pemanenan mengakibatkan terjadinya penurunan kerapatan pada setiap vegetasi penurunan terbesar terdapat diameter 50-59,9 s/d 80-89,9 cm ini dikarenakan banyak pohon yang berdiameter besar dilakukan pemanenan atau di lakukan penebangan. 
KESIMPULAN DAN SARAN

\section{Kesimpulan}

Berdasarkan Hasil Penelitian maka didapat disimpulkan sebagai berikut :

1. Komposisi Jenis Vegetasi yang terdapat pada Areal ET +5 adalah sebanyak 24 Jenis tingkat semai, 29 Jenis tingkat pancang, 15 jenis tingkat tiang dan 32 jenis tingkat Pohon, sedangkan pada areal sebelum penebangan terdapat 22 jenis tingkat semai, 38 jenis tingkat pancang, 35 jenis tingkat tiang dan 61 jenis tingkat pohon.

2. Struktur tegakan diliat dari kerapatan pada areal ET+5 yaitu tingkat Semai didominasi oleh Medang dan Ubah, tingkat Pancang Medang dan kumpang, tingkat Tiang Ubah dan Medang, dan tingkat Pohon Ubah dan Meranti Merah, sedangkan pada areal sebelum penebangan tingkat semai di dominasi oleh Meranti Kuning dan Ubah, tingkat pancang didominasi oleh Mahabai dan Ubah , tingkat tiang Ubah dan Sampak dan tingkat pohon didominasi oleh Ubah dan Medang.

3. Struktur tegakan pada ET+5 yang paling dominan adalah tingkat semai
Medang (Litsea sp), Ubah (Euginea sp.), Mahabai (Polyalthia hypoleuca), tingkat pancang Kumpang (Myristica sp), Medang (Litsea sp), Timau (Cratoxylon arborescens), tingkat tiang Ubah (Euginea sp), Medang (Litsea sp), Meranti Merah (Shorea leprosula), dan pada tingkat pohon Ubah (Euginea sp.), Meranti Merah (Shorea leprosula), Medang (Litsea $s p)$. Sedangkan pada areal sebelum penebangan yang paling dominan adalah pada tingkat semai Medang (Litsea sp), Ubah (Euginea sp), Meranti Kuning (Shorea gibbosa), pada tingkat pancang Mahabai (), Ubah (Euginea sp), Medang (Litsea $s p)$, pada tingkat Tiang Ubah (Euginea sp), Garung (Macaranga hypoleuca), Sampak (Aglaia sp), pada tingkat Pohon Ubah (Euginea sp), Meranti Kuning (Shorea gibbosa), Medang (Litsea sp).

\section{Saran}

1. Perlu dilakukan pengamatan lebih lanjut pada plot permanen yang telah dibuat terhadap riap pertumbuhan yang ditanam.

2. Perlu dilakukan penelitian sejenis dengan membandingkan famili 
sebaran terpilih dengan famili

sebaran yang berbeda serta perlu

dilakukan penelitian selanjutnya dengan sistem silvikultur yang berbeda.

\section{DAFTAR PUSTAKA}

Anwar J, SJ Damanik, N Hisyam dan AJ Whitten. 1984. Ekologi ekosistem sumatra. Gadjah Mada Univesity Press, Yogyakarta.

Departemen Kehutanan. 1999. Undangundang 41 Tahun 1999 tentang Kehutanan. Dephut RI. Indonesia.

Departemen Kehutanan. 1992. Manual Kehutanan. Departemen Kehutanan Republik Indonesia. Jakarta.

Departemen Kehutanan. 1993. Pedoman dan Petunjuk Teknis Tebang Pilih Tanam Indonesia (TPTI) pada Hutan Alam Daratan. Direktorat Jenderal Pengusahaan Kehutanan. Jakarta.

Falkultas Kehutanan UGM. 2004. Visi

Silvikulturis Indonesia Menyongsong Kehutanan 2045. Yogyakarta.

Faperta UNKA.2010. Pedoman Penulisan Skripsi.UNKA Sintang.

Manan, S. 1976. Dasar-Dasar Ekologi (Suatu Pengantar untuk Memahami Ekosistem). Lembaga Kerjasama Fakultas Kehutanan IPB. Bogor.

Meyer HA, B Recnagel, DD Stevenson, and Bartoo. 1961. Forestt
Management Second Edition.

New York: The Roland Press

Company.

Muhdi. 2001. Studi Kerusakan Tegakan

Tinggal Akibat Pemanenan

Kayu dengan Teknik

Pemanenan Kayu Berdampak

Rendah dan Konvensional di Hutan Alam (Studi Kasus di Areal HPH PT. Suka Jaya Makmur, Kalimantan Barat). Tesis Pasca Sarjana IPB. Bogor. Tidak Dipublikasikan.

Prasetyo, D. 2006. Kajian Komposisi dan Struktur Tegakan serta Pertumbuhan Jenis-jenis Komersial, Khususnya Jenis Ramin (Gonystylus bancanus (Miq.) Kurz.) di Hutan Rawa Gambut IUPHHK PT. Diamond Raya Timber, Propinsi Riau. Skripsi Sarjana IPB. Bogor. Tidak Dipublikasiakan.

Sastrodimedjo, S. 1992. Eksploitasi Hutan. Sekretariat Jenderal Departemen Kehutanan. Jakarta.

Soekotjo, 2009. Teknik Silvikultur Intensif. Gadjah Mada University Press. Yogyakarta.

Soekotjo, W. 1977. Silvika. Departemen manajemen Hutan Fakultas Kehutanan IPB. Bogor.

Soerianegara, I., A Indrawan. 1998. Ekologi Hutan Indonesia. Bogor.

Soerianegara, I. 1996. Ekologi, Ekologisme dan Pengelolaan Sumberdaya Hutan. Jurusan Manajemen Hutan. Fakultas Kehutanan IPB. Bogor. 
